\title{
Living Through the In-Between: T. S Eliot's Philosophy of Human Existence
}

Manuscript ID:

ENG-2021-09044040

Volume: 9

Issue: 4

Month: September

Year: 2021

P-ISSN: 2320-2645

E-ISSN: 2582-3531

Received: 18.05.2021

Accepted: 20.8.2021

Published: 01.09.2021

Citation:

Mathew, Raisun. "Living Through the In-Between: T. S Eliot's Philosophy of Human Existence." Shanlax International Journal of English, vol. 9, no. 4, 2021, pp. 9-13.

DOI:

https://doi.org/10.34293/ english.v9i4.4040

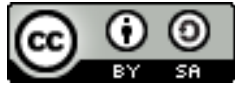

This work is licensed under a Creative Commons Attribution-ShareAlike 4.0 International License

\author{
Raisun Mathew \\ Doctoral Research Scholar, Department of English \\ Lovely Professional University, Punjab, India \\ https://orcid.org/0000-0003-3427-0941
}

\begin{abstract}
This research paper aims to highlight the philosophical perspective of T. S. Eliot on the existence of modern human beings on earth. The recurring meaninglessness and alienation expressed in the poems "The Waste Land" and "The Hollow Man" are discussed based on the context in which the poet correlateswith the reality experienced by the people. The encroachment of modernity of the twentieth-century civilization points to the loss of individual traditions, rootlessness and disorientation. The perpetual enquiries on the binaries are negated through the introduction of the intermediary space of existence. Certain vocabulary used in the poems throws light onto the existence of the poetic subjects in their in-between states referring to the presence of neither/nor situations. The fundamental nature of the reality and existence characterised by Eliot is revealed through the analysis of the poems as an experience of identity crisis amidst the politico-social situations leading to uncertain, anxious and ambiguous states of living. The paper concludes with the discovery of liminality and liminal existence of the poetic subjects that represent the existence of human beings regardless of time and place.
\end{abstract}

Keywords: Eliot, Liminality, Modernism, No-man's land, Uncertainty, Waste land

\section{Introduction}

The last quarter of the nineteenth century that saw the emergence of Modernism in France had its influential effect in Europe until the end of the Second World War. Unlike before, the period that lasts for about more than five decades saw the inception of various movements and trends in literature and art. The traditional writing styles that had been followed till then began to exit from the mainframe to accommodate experimental and complex forms. Discussions and discoveries about conscious and unconscious self by Sigmund Freud, the stream of consciousness by William James, absurdity by Albert Camus, existentialism and nihilism by Friedrich Nietzsche paved the path to new identities to the writing styles, themes and contexts in literature. T. S. Eliot (1888 - 1965) and his works can also be categorised to this avant-garde flow. Being a poet, philosopher, and a literary critic, Eliot's authenticity in expressing the commontone of the modernist period is well-projected in the major works that have also been reflected in the Nobel Prize in Literature (1948) presented to him. Though several poems have been written by him, the poems "The Love Song of J. Alfred Prufrock" published in 1915, "The Waste Land" (1922), "The Hollow Men"(1925), "Journey of the Magi" (1927), "Ash Wednesday" (1930), and Four Quartets (1943) are considered as his masterpieces. The unconventionality presented in the works which were quite unfamiliar to the readers of the time made him unique and associated with the changing situations of the time. Apart from the poetic excellence, his plays Murder in the Cathedral (1935) and The Cocktail Party (1949) have also attracted widespread attention. 
The present paper would discuss the poems "The Waste Land" and "The Hollow Men" for the expression of meaninglessness, absurdity and alienation. Through the textual and interpretive analysis of the two poems that represent the instability and existentialist characteristics of the modern period that was highly influenced by various socio-political events as well as the two major wars (WW1 and WW2), the in-between state of human beings expressed through the characters and situations are discussed. Scholarly perspectives that explore the major thematic concerns of the poems are gathered to substantiate the argument that the poems, directly and indirectly, point to the threshold states of existence.

\section{Literature Review}

Being a major influence in framing unconventional styles in writing and inculcating philosophical and religious connotations to select poems, the works of $\mathrm{T}$. S. Eliot has been widely researched throughout the six to seven decades for different aspects. Therefore, the most appropriate scholarly works that describe various aspects of the two poems - "The Waste Land" and "The Hollow Men" are discussed as part of the review of the literature.

Chetana Sharma (2015) draws a relation between the works of the most celebrated modernist writers such as James Joyce, Samuel Beckett and T. S. Eliot. Through the analysis of Eliot's "The Waste Land" with that of Joyce's A Portrait of the Artist as a Young Man and Beckett's Waiting for Godot, the existential approach in highlighting the disorientation and confusion prevalent in the works are traced. Dabas (2018) observes the projected time and history in "The Waste Land" creates a utopic atmosphere going beyond the literal meaning of time through the reflection of past and present. It concludes with the opinion that the poem presenting the interpretation of urban alienation became an inspiration to the postwar readers and writers (363). Pani (2013) emphasises the self-transcending character of human existence through a philosophical and existential exploration of the poem. The author expresses the view that Eliot explored the philosophy of existentialist thinkers through detailing the alienation and meaninglessness in his poems (302). Describing the poem "The
Waste Land", the article presents the dryness and infertility that dominates the poem wherein the earth is considered to be a 'dead land' with 'dull roots' and 'stony rubbish' that has impotent qualities (Pani 303). Trosman (1974) notes "The Waste Land" as a classic example for its composition that follows a psychological decompensation. According to the author, the poem had been a result of the multiple psychological stresses, purposelessness and exhaustion produced by the former years before the composition of the poem (717).

Hasan (2019) conducts an analytic study of "The Hollow Men" through textual and reader-response analyses highlighting the themes of religion, spirituality, meaninglessness and nothingness. The belief of Eliot about the hollowness of people from their insides resembling a scarecrow is presented in the paper through hope and nihilism expressed in the poem. The conclusive comments of the author state the spiritual deadness, fearfulness and despair that are demonstrated in the poem wherein the hollow men reflect the situations of the society after the First World War (Hasan180-181). Urquhart (2010) interprets "The Hollow Men" as the speaker's quest for meaning midst of the opposing spheres of existence which ends up in the inability to discover a balance between the physical and the abstract world causing dissatisfaction and mental imbalance (199). The author interprets various textual references to substantiate the argument presented in the article. Singh (2013) traces the prevalence of dilemma in "The Hollow Men" highlighting the chaos of modern existence. The author has the opinion that the poem records the drama of human affair wherein the irresponsible individuals repent for the outcome of their thoughtless misdeeds (2). The paper discusses the five parts of the poem through an interpretive analysis based on materialism, religion and spirituality.

\section{The No-Man's Land: Eliot's The Waste Land}

Written shortly after the First World War that caused immense destruction to both Britain and America, the context of the poem has a close connection with the survivors in their unfortunate post-war conditions. The existential nature of life that is mostly projected with alienation and isolation 
is portrayed in the poem representing the deadening pictures of modern society. The high usage of imagery and metaphor in the poem exhibits the modern society as a wasteland equal to a rocky barren place that lacks the presence of water for sustenance. The images of the crowd that stream across the London Bridge (Eliot, lines 62), the meeting with the former soldier in the crowd (line 69), the discontinuity between the woman and the man who does romance leading to dislikes (lines 249-256), the pleading woman requesting the speaker to talk to her and the speaker who denies (lines 111-114), and the need of money for Lil for an abortion (lines 139-172) shows the gradually developing plot of uncertainty and anxiety. In the first section of the poem, the speaker says

Speak, and my eyes failed, I was neither

Living nor dead, and I knew nothing,

Looking into the heart of light, the silence.

(Eliot, The Waste Land and Other Poemslines 39-41)

The unfortunate situation of people of the modern society is depicted through the lines. Here, the inbetween state - being neither one nor the other - is directly stated in the poem. Also, in the last section of the poem, the speaker says

Dead mountain mouth of carious teeth that cannot spit

Here one can neither stand nor lie nor sit

There is not even silence in the mountains

But dry sterile thunder without rain

There is not even solitude in the mountains

But red sullen faces sneer and snarl

From doors of mud-cracked houses

(Eliot, The Waste Land and Other Poemslines 339-340)

Each line from the extract of the poem provided above gives hint to the absolute emptiness where silence and solitude that represent the settled stability of the situations are lacking. The impotence and contrasting images shown in the poem presents the ambiguous passage between life and death, commonly tracing a limbo-like existence (Pandya and Mathew 22). The wasteland existence of the society provides no space for any activity that is wished to be pursued by the people. The unfulfilled hopes of human beings are represented through the lines that highlight the presence and absence of associated activities.

\section{The Limbo State: Eliot's The Hollow Men}

Emptiness and meaninglessness of the life of people after the First World War is represented through the hollow men in the poem. The use of certain expressions and imagery such as broken glass (Eliot, "The Hollow Men" line 9), stuffed men having headpiece filled with straw (line 2-4), dried voices (line 5), shape without form, paralysed force, and gesture without motion and shade without colour (line 11-12) etc. denotes the overall tone of the poem that points to the absurd and ambiguous state of existence. The speaker of the poem repeats the same lines

We are the hollow men

We are the stuffed men

(Eliot, "The Hollow Men” lines 1-2)

Also, the setting of the poem - between death and life, existence and nothing, and light and darkness denote the existence of the speaker and other hollow men in a purgatory-like condition representing the inbetween state of living. The war land - similar to the wasteland has been equated to a cactus land where the lifelessness of the world is highly projected through the in-between state of the speaker. The position of the speaker can be identified as an intermediary space that has no qualities attached to the previous or the post-stages or conditions. The uncertainty and anxiety in the lines spoken from the perspective of the speaker present the fear and loss of their fruitful existence - an unsatisfactory condition of neither able to access their past nor the future.

The in-between state of the hollow men is well reflected in the lines that depict the intermediate conditions of the speaker. The hollowness and limbo situation of the speaker can be traced from the image of shadow that falls between idea and reality (Eliot, "The Hollow Men"lines 72-73), motion and act (lines 74-75), conception and creation (lines 7879), emotion and response (lines 80-81), desire and spasm (lines 84-85), potency and existence (lines 8687), and essence and descent (lines 88-89) 


\section{Discussion and Findings}

Throughout the analysis of the two poems "The Waste Land" and "The Hollow Men", the most recurring situation of the speakers is their threshold state - i.e. living in-between two binary opposites wherein the intermediate space denotes instability and unusualness. These representations of threshold states point to the liminal existence of the speakers and the lives that they represent in the poem. According to the anthropological explanations by the British anthropologist and symbologist Victor Turner, liminality refers to the intermediate state of the rites of passage introduced by Arnold van Gennep where it represents the in-between state that produces neither one nor the other condition. It produces the betwixt and between the existence of the liminal entities (those who are an active part of the process of transition from pre-liminal to the post-liminal phases) reflecting the uncertainty, anxiety, ambiguity and unusualness of the situation or state of experience. The anti-structural identity of the liminal entity in the poem is defined by the various descriptions that have been discussed in the previous sections of this paper. As man is considered to be a transitional being having both the qualities of structural and anti-structural existence in the world (Turner 298), the poem's depiction of the in-between state of existence due to the unfortunate after-effects of the war can hopefully be regarded as temporary.

\section{Conclusion}

Identifying the hollowness discussed through the two poems through the lens of liminality, the paper would like to conclude by stating the relevance of Eliot's philosophy about human beings. Though it had been written on the background and influence of the First World War, similar situations - in various dimensions of life - occur at various phases of life of humans on earth. The temporary and permanent forms of liminality wherein the liminal entities exist in a short phase and long phase of such intermediary situations cannot be disregarded for its scope of existence. The prevailing pandemic condition is a contemporary example of such liminal existence of people who go through similar conditions of hollowness, meaninglessness expressing emotional numbness, desolation and fearful situation of life
(Pandya 34) becoming entrapped in the unusual and unstable state between the pre-pandemic and the post-pandemic phases. Thus, the philosophical overtones of the poem in relation with the existence of human beings on earth can be understood beyond the spatial and temporal limits.

\section{References}

Dabas, Komal. “T. S. Eliot's Concept of Time and History in 'The Waste Land'." Research Journal of English Language and Literature, vol. 6, no. 1, 2018, pp. 362-363.

Eliot, T.S. The Waste Land and Other Poems. Barnes Noble Classics, 2005.

Eliot, T.S. "The Hollow Men." Glencoe Literature British Literature. The McGraw-Hill, 2000.

Hasan, Mariwan. “A Thematic Investigation into T.S. Eliot's 'The Hollow Men': With Reference to Textual Approach." Critical Literary Studies, vol. 1, no. 2, 2019, pp. 159-184.

Pandya, Digvijay, and Raisun Mathew. "Betwixt and Between: Liminal Existence in T. S. Eliot's The Hollow Men." The Interdisciplinary Hermeneutic Reappraising the Socio-Cultural Episteme, edited by Pavitar Parkash Singh, Anamika Publishers \& Distributors, 2020.

Pandya, Titixa. "The Portrayal of Pandemic in T. S Eliot's The Waste Land." Historical and Literary Perspectives of Humanity during Pandemic, edited by Pushpa Dixit, Red'Shine Publication, 2020, pp. 27-42.

Pani, Praja. "Reflections on the Existential Philosophy in T.S. Eliot's Poetry." Cosmos and History: The Journal of Natural and Social Philosophy, vol. 9, no. 1, 2013, pp. 301-316.

Sharma, Chetana. "Existential Approach in the Works of James Joyce, T.S. Eliot and Samuel Beckett." Scholar Critic, vol. 2, no. 1, 2015.

Singh, Renu. "A Study of Dilemma in The Hollow Men of T.S. Eliot." Galaxy: International Multidisciplinary Research Journal, vol. 2, no. 3, 2013.

Trosman, Harry. "T. S Eliot and the Waste Land: Psychopathological Antecedents and Transformations." Archives of General 
Psychiatry, vol. 35, no. 5, 1974, pp. 709-717.

Turner, Victor. Dramas, Fields, and Metaphors:

Symbolic Action in Human Society. Cornell
University Press, 1974.

Urquhart, Troy. "Eliot's The Hollow Men." The Explicator, vol. 59, no. 4, 2010, pp. 199-201.

\section{Author Details}

Raisun Mathew, Doctoral Research Scholar, Department of English, Lovely Professional University, Punjab, India, Email ID: raisunmathew@gmail.com. 